\title{
LATVIJAI AKTUĀLIE JAUTĀJUMI SINGAPŪRAS MEDIĀCIJAS KONVENCIJAS KONTEKSTĀ
}

\section{QUESTIONS RELEVANT FOR LATVIA IN THE CONTEXT OF SINGAPORE CONVENTION ON MEDIATION}

\author{
Liga Kirstuka, $M g$. iur.
}

\section{Summary}

Latvia is a part of the international trade environment, whose development can be significantly affected by unresolved conflicts. In 2019, the United Nations adopted the Convention on International Settlement Agreements resulting from Mediation (the Convention) with the aim of promoting the development of international economic relations and mediation as an effective means of dispute resolution through the harmonization of the legal framework for enforcement of international settlement agreements resulting from mediation. The author of the article looks at the situation of Latvia in the sphere of enforcement of mediation agreements from the perspective of the Convention. Comparing the common and different aspects of the legal framework currently in force in Latvia and the Convention, which will enter into force on 12 September 2020 , the author addresses the issues of definition and principles of mediation, offers solutions for necessary changes to achieve the purpose of the Convention in Latvia, and to improve the legal regulation.

Atslēgvārdi: mediācija, konvencija, mediācijas vienošanās izpilde, mediatori, starptautiski komercstrīdi

Keywords: mediation, convention, enforcement of mediation settlement agreement, mediators, international commercial disputes

\section{Ievads}

Apvienoto Nāciju Organizācijas (ANO) G̣enerālā Asambleja 2018. gada 20. decembrī pieñēma ${ }^{1}$ Starptautisko tirdzniecības tiesību komisijas (turpmāk - UNCITRAL) izstrādāto ANO Konvenciju par mediācijas rezultātā noslēgtiem starptautiskiem vienošanās lïgumiem² (the UN Convention on International Settlement Agreements resulting from Mediation; turpmāk - Konvencija), saukta

\footnotetext{
1 ANO G̦enerālās Asamblejas 20.12.2018. rezolūcija Nr. A/RES/73/198. Pieejams: https://undocs.org/ en/A/res/73/198 [aplūkots 26.02.2020.].

2 Neoficiāls Konvencijas nosaukuma tulkojums.
} 
arī par Singapūras Mediācijas konvenciju (Singapore Convention on Mediation). ${ }^{3}$ Konvencijas preambulā uzsvērta mediācijas būtiskā loma starptautisko tirdzniecības strīdu risināšanā. ${ }^{4}$ Viens no Konvencijas galvenajiem mērḳiem ir nodrošināt mediācijas procesā noslēgtu starptautisku vienošanos atzī̌sanu un izpildi. Ieviešot noteiktību un stabilitāti mediācijas starptautiskajā regulējumā, tiktu veicināta Ilgtspējīgas attīstības plāna (Sustainable Development Goals (SDG), mainly the SDG 16) īstenošana, sekmējot harmonisku starptautisko ekonomisko attiecību attīstību. ${ }^{5}$

Konvencijas parakstī̌̌ana tika uzsākta 2019. gada 7. augustā Singapūrā. Pašlaik to ir parakstījušas 52 valstis. Singapūra un Fidži, 2020. gada 25. februārī ratificējot Konvenciju, kḷuva par Konvencijas dalībvalstīm. Savukārt 2020. gada 12. martā Konvencijas dalībvalstu lokam pievienojās Katara, ${ }^{6}$ tādējādi iedarbinot Konvencijas spēkā stāšanās mehānismu, kas paredz tās stāšanos spēkā sešu mēnešu laikā pēc vismaz trīs valstu kḷūšanas par Konvencijas dalībvalsti. ${ }^{7}$ Attiecīgi Konvencija stāsies spēkā 2020. gada 12. septembrī.

Konvencija ir piemērojama mediācijas procesa rezultātā rakstveidāe noslēgtiem vienošanās dokumentiem, kas atrisina komercstrīdu, kurš uz mediācijas vienošanās noslēgšanas brīdi ir starptautisks. ${ }^{9}$ Aplūkojot mediācijas jomas, konstatējams, ka Konvencija nav piemērojama tādiem vienošanās dokumentiem, kas noslēgti, lai atrisinātu strīdu, kas pusei radies, darījumā iesaistoties personisku, ǵimenes vai mājsaimniecības iemeslu dēḷ. Tāpat Konvencija neattiecas uz vienošanās dokumentiem, kas saistīti ar ǵimenes, mantošanas vai nodarbinātības tiesisko regulējumu. ${ }^{10}$

Attiecībā uz Konvencijas piemērošanu, ja puses ir izmantojušas tiesu vai šķ̄irējtiesu kā strīdu risināšanas veidu, Konvencija nav piemērojama tiesu apstiprinātajiem vienošanās dokumentiem vai tādiem, kas ir noslēgti tiesvedības laikā, kā arī tādiem vienošanās dokumentiem, kas ir izpildāmai kā tiesas spriedums attiecīgās valsts tiesā. Arī mediācijas procesā noslēgtās vienošanās, kas reg̣istrētas un izpildāmas kā šḳirējtiesu lēmumi, ir ārpus ši Konvencijas tvēruma. ${ }^{11}$

Raksta turpinājumā tiek aplūkota Latvijas situācija mediācijas rezultātā noslēgtas vienošanās piespiedu izpildes jomā, raugoties uz to caur Konvencijas prizmu. Salīdzinot kopīgo un atšķirīgo pašlaik spēkā esošajā tiesiskajā regulējumā Latvijā un Konvencijā, kura stāsies spēkā 2020. gada 12. septembrī, tiek aplūkoti jautājumi par mediācijas definìciju un principiem, par nepieciešamajām izmaiṇām Latvijas tiesiskajā regulējumā Konvencijas mērḳa sasniegšanai Latvijā,

${ }^{3}$ UN Convention on International Settlement Agreements resulting from Mediation [ANO Konvencija par mediācijas rezultātā noslēgtiem starptautiskiem vienošanās līgmiem]. Pieṇemta: N̦ujorka, 20.12.2018. Pieejams: https://treaties.un.org/doc/Treaties/2019/05/20190501\%2004-11\%20PM/ Ch-XXII-4.pdf [aplūkots 04.03.2020.].

${ }^{4}$ Konvencijas preambula.

5 UNCITRAL: United Nations Convention on International Settlement Agreements Resulting from Mediation (New York, 2018) (the "Singapore Convention on Mediation"). Available at: https://uncitral. un.org/en/texts/mediation/conventions/international_settlement_agreements [aplūkots 03.03.2020.].

${ }^{6}$ United Nations Treaty Collection [ANO Līgumu datubāze]. Available at: https://treaties.un.org/pages/ ViewDetails.aspx?src=TREATY\&mtdsg_no=XXII-4\&chapter=22\&clang=_en\#EndDec [aplūkots 13.03.2020.].

7 Konvencijas 14. panta pirmā daḷa.

${ }^{8}$ Konvencijas 2. panta otrā daļa.

${ }^{9}$ Konvencijas 1. pants.

${ }^{10}$ Konvencijas 2. pants.

11 Konvencijas 1. panta trešā dal̦a. 
tiek piedāvāti risinājumi mediatoru kā mediācijas pakalpojuma sniedzēju darbības tiesiskā regulējuma pilnveidošanai.

\section{Mediācijas definīcija un principi}

Pieņemot Mediācijas likumu, likumdevējs definēja, ka Latvijā ar mediāciju saprot brīvprātīgu sadarbības procesu, kurā puses cenšas panākt savstarpēji pieņemamu vienošanos savu domstarpību atrisināšanai ar mediatora starpniecību. ${ }^{12}$

Konvencijā skaidrojums par mediāciju atrodams gan tās preambulā, gan Konvencijas 2. panta trešajā daḷā. Preambulā iekḷautajā skaidrojumā sašaurināta Konvencijas piemērošana, norādot, ka mediācija ir metode komercstrīdu izškịiršanai, tādējādi izslēdzot Konvencijas piemērošanu citās jomās, kur varētu rasties konflikta situācijas. Taču, ņemot vērā, ka ar Konvencijas palīdzību ir vēlme veicināt ìpaši starptautiskās tirdzniecỉbas attiecības, ${ }^{13}$ šāds Konvencijas piemērošanas sašaurinājums ir pamatots un nepieciešams.

Ja aplūko mediācijas tiesisko regulējumu Latvijā atbilstoši tiesību nozarēm un strīdā iesaistītajām pusēm, secināms, ka tas atbilst Konvencijas saturam, jo Mediācijas likums aptver komercstrīdus, savukārt uz publiskām personām, kuras darbojas privāto tiesību jomā, attiecas tiesību akti, kas reglamentē privāttiesiskus darījumus vispār, ar atrunu - ciktāl publisko personu darbību neierobežo citi normatīvie akti. ${ }^{14}$

Saskaṇā ar Konvencijas 8. pantu, pievienojoties Konvencijai, dalïbvalsts var veikt divu veidu atrunas, paredzot, ka Konvencija netiks piemērota, ja viena no strīda pusēm ir pati dalībvalsts, jebkura šis valsts institūcija vai jebkura persona, kura rīkojas attiecīgās institūcijas vārdā, norādot piemērošanas ierobežojumu apjomu. ${ }^{15}$ Šādu atrunu ir veikusi Baltkrievija un Irāna. ${ }^{16}$ Otrs gadijums dod tiesības dalībvalstij veikt atrunu, paredzot, ka Konvencija ir piemērojama tiktāl, ciktāl mediācijas puses ir vienojušās par Konvencijas piemērošanu. ${ }^{17}$ Šādu atrunu ir veikusi Irāna. No vienas puses, dalībvalstij veicot šādu atrunu, tiek paplašināts pušu pašnoteikšanās principa tvērums, taču, no otras puses, tiek ierobežota Konvencijas piemērošana mediācijas vienošanās piespiedu izpildes nepieciešamības gadījumā, kas var negatīvi ietekmēt starptautisko ekonomisko attiecību attīstību.

Būtiski uzsvērt, ka Konvencijā nav definēti vai tiešā veidā minēti mediācijai piemērojamie standarti vai ètikas principi, taču to neievērošana mediatora darbā var radìt juridiskas sekas, proti, izslēdzot Konvencijas piemērojamību, ja mediatora pārkāpums ir radījis Konvencijā noteiktās sekas kādai no pusēm. ${ }^{18}$

Tāpat ir uzsvērta pušu pašnoteikšanās, izvēloties strīdu risināt mediācijas procesa ietvaros un izvēloties mediatoru, kā arī nosakot mediatoru skaitu, kas

\footnotetext{
12 Mediācijas likums, 1. panta 1. punkts: LV likums. Pieṇemts 04.06.2014. [03.03.2020. red.].

13 Konvencijas preambula.

14 Valsts pārvaldes iekārtas likums, 87. panta otrā daḷa: LV likums. Pieṇemts 21.06.2002. [20.01.2020. red.].

15 Konvencijas 8. panta pirmās daḷas (a) apakšpunkts.

${ }^{16}$ United Nations Treaty Collection [ANO Līgumu datubāze]. Available at: https://treaties.un.org/pages/ ViewDetails.aspx?src=TREATY\&mtdsg_no=XXII-4\&chapter=22\&clang=_en\#EndDec [aplūkots 26.02.2020.].

17 Konvencijas 8. panta pirmās daḷas (b) punkts.

18 Konvencijas 5. panta pirmā daḷa.
} 
vadīs mediāciju. ${ }^{19}$ Salīdzinot ar Latvijā spēkā esošo mediācijas definīciju, Mediācijas likumā pušu pašnoteikšanās princips ir nosaukts par brīvprātības principu, abiem principiem pēc būtības regulējot līdzīgus jautājumus, tostarp, pušu tiesības brīvi lemt par piedalī̌sanos mediācijā, mediācijas uzsākšanu, mediatora izvēli. ${ }^{20}$ Mediatora spēja ietekmēt vai rīcība, ietekmējot puses saistībā ar konkrēta risinājuma izvēli pušu strīdam, atbilstoši Konvencijā iekḷautajai mediācijas definīcijai tiek uzskatīta kā viena no raksturojošām pazìmēm, kas izslēdz attiecīgā procesa atbilstību mediācijas procesam un ir atzīstama kā pamats Konvencijas piemērošanas atteikumam. ${ }^{21}$

Tāpat gan Konvencijā, gan Mediācijas likumā ir iekḷauts mediācijas pušu pienākums censties rast risinājumu. Konvencijā ir norāde, ka mediācijas procesam ir raksturīgs pušu mēǵinājums miermīlìgā ceḷā panākt vienošanos, savukārt mediācijas definīcijā Latvijā papildus ir iekḷauta norāde, ka mediācijas rezultātam ir jābūt savstarpēji pieņemamam. Tātad Latvijas Republikas Saeima ir noteikusi, ka mediators nedrīkst aprobežoties tikai ar atbalsta sniegšanu pusēm risinājumu meklēšanā, bet ir nepieciešams pievērst īpašu uzmanību pušu vienošanās satura savstarpējās pieņemamības pārbaudei. Šãda norāde nerada šķērěșlus Konvencijas îstenošanai pēc būtỉbas, ja tiek ņemti vērā citi Konvencijas noteikumi.

Salīdzinot Konvencijas 2. panta trešajā dal̦a iekḷauto mediācijas definīciju, kas papildina Konvencijas preambulā ietverto, ar Latvijā lietoto mediācijas definīciju, secināms, ka Konvencijas mērķa sasniegšanai pēc iespējas tiek novērsti šķēršs̆li, lai formālu iemeslu dẹl, piemēram, mediācijas procesa apzīmēšanai izmantots cits nosaukums ${ }^{22}$ netiktu ierobežota Konvencijas piemērošana mediācijas rezultātā panāktas vienošanās izpildei. Latvijā mediatora funkciju veikšana Mediācijas likumā tiek saukta par starpniecỉbu, ${ }^{23}$ bet Konvencijā tiek lietots vārds asistēšana jeb atbalsts, kas precīzāk raksturo mediatora lomu mediācijas procesā.

N̦emot vērā mediācijas definīcijas satura salīdzinājumu Mediācijas likumā un Konvencijā, secināms, ka Latvijā lietotā mediācijas definīcija ir atbilstoša Konvencijas piemērošanai, ja Mediācijas likumā tiek precizēts jautājums saistībā ar mediatora varu uzspiest strīdā iesaistìtajām pusēm konkrētu risinājumu. Viens no risinājumiem ir Mediācijas likuma 3. panta grozišana, kurā ietverts brīvprātības principa regulējums, papildinot to ar pušu tiesībām brīvi lemt par mediācijas procesā panāktas vienošanās saturu bez mediatora vai trešo personu iejaukšanās.

Mediācijas definīcijā neietverts, bet aktuāls ir jautājums, ciktāl mediācijas procesa konfidencialitāte attiecas uz mediācijas procesā panāktu vienošanos. Piemēram, vai mediācijas vienošanos puses drīkst izmantot kā pierādījumu tiesā, tas ir, atsaukties uz to, un vai šādā gadỉjumā joprojām tiek nodrošināta Mediācijas likumā paredzētā konfidencialitātes principa ${ }^{24}$ ievērošana. Citādi formulējot jautājumu, būtu jāvērtē, vai, parakstot vienošanos, pušu konfidencialitātes princips attiecībā uz vienošanās tekstu un pašu dokumentu nav piemērojams.

\footnotetext{
19 Konvencijas preambula.

${ }^{20}$ Mediācijas likuma 3. pants.

${ }^{21}$ Konvencijas 2. panta trešā daḷa.

22 Ibid.

${ }^{23}$ Mediācijas likuma 1. panta 1. punkts.

${ }^{24}$ Mediācijas likuma 4. pants.
} 
Tāpat - kāda ir konfidencialitātes principa īstenošana mediācijas procesā un, ja nepieciešama mediācijas vienošanās piespiedu izpilde, attiecīgā izpildes procesa savstarpējā saskan,otība. Latvijai, lemjot par pievienošanos Konvencijai, par iepriekš aprakstīto jautājumu būtu jāveic rūpīgs un padziḷināts izvērtējums, lai novērstu iespējamās pretrunas tiesību aktu līmenī un pēc iespējas samazinātu risku - pušu uzticības zaudēšanu mediācijai kā strīdu risināšanas procesam, kura viens no stūrakmeņiem ir konfidencialitātes nodrošināšana.

Atšķirības tiesību aktos ietvertajās mediācijas definīcijās un izpratnē par mediācijai un mediatoriem piemērojamiem standartiem, tostarp ètikas principiem, var radīt būtiskus škseerršlus Konvencijas mērķa sasniegšanai. Līdz ar to raksta turpinājumā plašāk aplūkoti mediācijas vienošanās piespiedu izpildes tiesiskie un praktiskie aspekti, piedāvājot risinājumus virzībai uz Konvencijas mērḳa sasniegšanu Latvijā.

\section{Konvencijas mērḳu sasniegšana Latvijā}

Viens no Konvencijas mērk̦iem ir harmonizèt ${ }^{25}$ tiesisko regulējumu saistībā ar tiesībām atsaukties ${ }^{26}$ uz mediācijas vienošanos, $k \bar{a}$ arī saistībā ar šādas vienošanās izpildi. Latvijas tiesiskajā regulējumā nav konkrēti atrunāta strīdu puses rīcība un tiesiskais rāmis mediācijas vienošanās neizpildes gadījumā. Šādos gadījumos ir piemērojamas tiesību nomas, kas nosaka strīdu risināšanas kārtību saistību daḷējas izpildes vai pilnīgas neizpildes gadījumā. Ja puses radušos strīdu nespēj atrisināt sarunu gaitā vai izmantojot citus ārpustiesas strīdu risināšanas veidus, pusēm ir tiesības vērsties tiesā ${ }^{27}$ un izmantot savu tiesību un interešu aizsardzībai valsts radīto tiesību aizsardzības mehānismu.

Attīstoties mediācijai Latvijā, aktualizējies ir jautājums par mediācijas vienošanās piespiedu izpildes institūta ieviešanu ar mērķi veicināt mediācijas kā strīdu risināšanas veida, kura ietvaros puses pašas uzṇemas atbildību par lēmuma pieņemšanu, efektīvu izmantošanu. Ja mediācija ir piemērota konkrēta strīda risināšanai, tad prakse liecina, ka mediācija kā strīdu risināšanas veids ir ātrāks nekā tiesas process. Taču, ja pušu vienošanās piespiedu izpilde nav iespējama vai arī process ir birokrātisks un laikietilpīgs, komercstrīdu risināšanai mediācija netiek izvēlēta.

Par mediācijas nozares politikas izstrādi atbildīgajai Tieslietu ministrijai, ${ }^{28}$ strādājot pie ši jautājuma, būtiski to aplūkot ne tikai Latvijas tiesību sistēmas ietvaros, bet jau savlaicīgi ņemt vērā Konvencijā paredzētos noteikumus un piemērošanas nosacījumus, tādējādi lietderīgi un efektīvi izmantojot politikas plānotāja resursus, vienlaicīgi veicinot pārrobežu mediācijas attīstību un ìstenojot Latvijas mērḳi būt valstij ar uzṇēmējdarbībai labvēlīgu vidi. ${ }^{29}$

\footnotetext{
${ }^{25}$ Konvencijas preambula: Konvencija tiktu īstenota valstīs ar atšḳirīgu tiesisko, sociālo un ekonomisko sistēmu.

26 The right to invoke.

27 Civilprocesa likums, 1. pants: LV likums. Pieņemts 03.11.1998. [27.01.2020. red.].

28 Tieslietu ministrijas nolikums: Ministru kabineta 16.08.2017. noteikumi Nr. 474, 4.1.16. punkts. Latvijas Vēstnesis, 18.08.2017., Nr. 164 [15.01.2020. red.].

${ }_{29}$ Par Uzṇēmējdarbības vides pilnveidošanas pasākumu plānu 2019.-2022. gadam: Ministru kabineta 22.05.2019. rīkojums Nr. 247. Latvijas Vēstnesis, 24.05.2019., Nr. 104 [03.03.2020. red.].
} 
Konvencija paredz katras tās dalībvalsts tiesības izveidot procedūru mediācijas rezultātā noslēgtas vienošanās izpildei, ņemot vērā Konvencijā ietvertos noteikumus. ${ }^{30}$ Viens no noteikumiem, kas izriet no Konvencija teksta, ${ }^{31}$ ir Konvencijas dalībvalsts pienākums izveidot vai noteikt kompetento iestādi, kura būtu atbildīga par Konvencijai atbilstošu mediācijas vienošanos izpildes procesa koordinēšanu, dokumentu izvērtēšanu un lēmumu pieņemšanu. Konvencijas tekstā nav ietverti ierobežojumi attiecībā uz kompetento iestāžu skaitu vai funkciju sadalìjumu, taču, aplūkojot Konvencijas preambulu, kā arī, ņemot vērā citos starptautiskajos tiesību aktos noteikto, ${ }^{32}$ izveidotajai tiesību aizsardzības sistēmai ir jābūt efektīvai un taisnīgai.

UNCITRAL norāda, ka Konvencija ir starptautiskās tirdzniecības veicināšanas, kā arī mediācijas kā alternatīvas un efektīvas tirdzniecības strīdu risināšanas metodes attīstīšanas instruments. ${ }^{33}$ Lai attiecīgā instrumenta izmantošana sasniegtu mērķi, īpaša uzmanība ir pievēršama nacionālajam regulējumam gan saistībā ar mediācijas vienošanās piespiedu izpildi, gan mediatoru darba kvalitāti.

\section{Mediatoru kā mediācijas pakalpojuma sniedzēju darbības tiesiskais regulējums}

Lai arī Latvija līdz šim nav publiski pieņēmusi lēmumu pievienoties Konvencijai, tās satura un piemērošanas pārzināšana ir būtiska ikvienam mediatoram, kurš vada komercstrīdus, ja mediācijā iesaistīto pušu saimnieciskā darbība un darījumu raksturs atbilst Konvencijas tvērumam. Konvencijā nav ietverti noteikumi par mediatora valstspiederību, kā arī Konvencijas piemērošana nav saistīta ar mediācijas pakalpojuma sniegšanas vietu vai veidu, piemēram, elektroniska komunikācija, tādējādi gan Latvijā, gan ar Latvijas mediatoru atbalstu vadìtas mediācijas rezultātā panāktas vienošanās piespiedu izpilde tiks īstenota jebkurā no Konvencijas dalībvalstīm pēc Konvencijas spēkā stāšanās, ja vien būs ievēroti Konvencijā paredzētie noteikumi.

Saskaņā ar Konvenciju mediators ir strīda risināšanai piesaistīta trešā persona, kurai nepiemīt vara uzspiest pusēm strīda risinājumu un kura sniedz atbalstu pusēm strīda risināšanā. ${ }^{34}$ Attiecīgā definīcija norāda gan uz mediatora statusu, proti, ka tā ir strīda risināšanai piesaistīta trešā persona, gan uz mediatora lomu un uzdevumu mediācijas procesā. Savukārt Mediācijas likumā ietvertā mediatora definīcija aptver mediatora statusu mediācijas procesā, raksturojot mediatoru kā pušu brīvi izraudzītu fizisko personu, kura ir piekritusi vadìt mediāciju. ${ }^{35}$ Mediatora loma uz uzdevumi mediācijas procesā ir izsecināmi no Mediācijas likuma citiem pantiem. Latvijā ir ieviests arī sertificētu mediatoru

\footnotetext{
30 Konvencijas 3. panta pirmā dal̦a.

31 Piemēram, Konvencijas 4. panta pirmā daḷa.

32 Cilvēka tiesību un pamatbrīvību aizsardzības konvencija. Parakstīta Romā 04.11.1950. [03.03.2020. red.].

33 UNCITRAL: United Nations Convention on International Settlement Agreements Resulting from Mediation (New York, 2018) (the "Singapore Convention on Mediation"). Available at: https://uncitral. un.org/en/texts/mediation/conventions/international_settlement_agreements [aplūkots 03.03.2020.].

34 Konvencijas 2. panta trešā daḷa.

35 Mediācijas likuma 1. panta 4. punkts.
} 
institūts, likumdevējam nosakot, ka sertificēts mediators ir normatīvajos aktos noteiktajā kārtībā apguvis mediāciju un sañēmis sertifikātu, kas dod tiesības tikt ieklıutam sertificētu mediatoru sarakstā. ${ }^{36}$ Secināms, ka Mediācijas likumā ietverto definīciju, mediatora lomas un uzdevumu saturs nav pretrunā ar Konvencijā noteiktajiem mediatoru raksturojošiem elementiem un nerada šķēršlus Konvencijas piemērošanai.

Viens no Konvencijā paredzētajiem pušu pienākumiem, iesniedzot mediācijas vienošanos piespiedu izpildei, ir pierādīt, ka vienošanās ir noslēgta mediācijas rezultātā. Konvencija paredz vairākus pierādijumu veidus, taču rakstā plašāk tiks aplūkoti divi no Konvencijā minētajiem. Viens no Konvencijā norādītajiem veidiem, kas tiek atzīts kā mediācijas rezultātā noslēgtas vienošanās pierādījums, ir mediatora paraksts uz attiecīgās vienošanās, bet otrs - mediatora parakstīts dokuments, kurā ietverts apliecinājums par notikušu mediāciju.

Pašlaik mediācijas tiesiskais regulējums Latvijā neuzliek pienākumu mediatoram parakstìt pušu noslēgtu vienošanos. Lai arī sertificētu mediatoru vidū noris diskusijas par šādas prakses ieviešanu, ja tas būtu nepieciešams, lai veicinātu efektīvu mediācijas vienošanos izpildi, taču izvērtējama ir mediatora paraksta uz mediācijas vienošanās nozīme un juridiskās sekas. Apsverams ir jautājums, vai mediatora paraksts uz mediācijas vienošanās ir tikai mediācijas norises apliecinošs fakts vai arī pastāv risks, ka šāda dokumentu noformēšanas kārtība apliecinātu mediatora daḷēju vai pilnīgu atbildỉbu par mediācijas vienošanās saturu.

Mediācijas procesa viena no svarīgākajām iezīmēm ir pušu pašnoteikšanās (brīvprātība), ${ }^{37}$ kas izpaužas arī atbildībā par lēmumu pieņemšanu un to saturu, taču tikpat svarīgs princips ir mediatora neitralitāte, kas veicina un nodrošina pušu uzticēšanos mediatoram un mediācijas procesam. Lēmumu pieṇemšana pušu vietā vai atbildības uzṇemšanās par pušu lēmumu saturu un izpildi ir pretrunā ar mediācijas būtību un mediatora ètikas principiem. Tādējādi, virzot priekšlikumu par mediatora parakstītu mediācijas vienošanos, tiesību aktos būtu nepārprotami jānosaka pušu un mediatora atbildības robeža saistībā ar mediācijas vienošanās saturu, likumā precīzi norādot, ka mediatora paraksts uz dokumenta ir apliecinājums mediācijas procesa norisei, izslēdzot iespēju tiesību aktu vai to piemērošanas prakses neatbilstošai interpretācijai strīda starp mediatoru un mediācijas dalībniekiem risināšanas gadijjumā.

Savukārt mediatora izsniegts dokuments par mediācijas norises faktu jau šobrīd ir ieviests Latvijas tiesiskajā regulējumā, proti, mediatoram ir tiesības un atseviškos gadījumos pat pienākums izsniegt pusēm apliecinājumu, kas ir rakstveida dokuments, kurā norāda puses, strīda priekšmetu, mediācijas izbeigšanas datumu un kurš Mediācijas likumā noteiktajos gadījumos apliecina mediācijas izbeigšanu ar vienošanos vai bez tās. ${ }^{38}$ Ja puses ir mediācijas rezultātā noslēgušas vienošanos, mediatoram nav pienākums izsniegt apliecinājumu, ja vien puses to nelūdz. Lai nodrošinātu Konvencijas efektīvu īstenošanu, apliecinājums par mediācijas norises faktu būtu izsniedzams visos gadijumos, kas atbilst Konvencijas tvērumam.

\footnotetext{
36 Mediācijas likuma 1. panta 5. punkts.

37 Mediācijas likuma 3. pants.

${ }^{38}$ Mediācijas likuma 1. panta 8. punkts.
} 
Konvencijas regulējumā par atteikumu veikt mediācijas vienošanās piespiedu izpildi ietverti divi nosacijumi, kas ir saistīi ar mediatora rīcību. Viens no tiem ir piemērojams, ja mediators ir būtiski pārkāpis mediatoram vai mediācijai piemērojamos standartus un ja puse attiecīgo standartu ievērošanas gadījumā nebūtu piekritusi noslēgt vienošanos. ${ }^{39}$ Savukārt otrs mediatora pārkāpums, kas var tikt norādīts kā vienošanās piespiedu izpildes atteikuma pamatojums, ir saistìts ar informācijas slēpšanu, proti, mediators pusēm nav atklājis apstākḷus, kas raisa pamatotas šaubas par mediatora objektivitāti vai neatkarību, un šāds atklātības trūkums ir vai nu radījis mediācijas pusei mantisku ietekmi, vai arī mediācijas puse, mediatoram īstenojot nepieciešamo atklātību, nebūtu piekritusi vienošanās noslēgšanai. ${ }^{40}$

Iestājoties jebkuram no aprakstìtajiem gadỉjumiem, tiek mazināta uzticēšanās mediācijai kā efektīvam strīdu risināšanas veidam. Tādējādi ir būtiski valstī izveidot efektīvu mediatoru darbības uzraudzības sistēmu, lai pēc iespējas novērstu šādu gadījumu rašanos un, iestājoties šādām situācijām, lai valsts spētu efektīvi nodrošināt personu tiesību aizsardzības mehānismu darbību, saglabājot un veicinot sabiedrības uzticēšanos mediācijai kā strīdu risināšanas veidam.

\section{Secinājumi}

1. Latvijā lietotā mediācijas definīcija ir atbilstoša Konvencijas piemērošanai, ja Mediācijas likumā tiek precizēts jautājums saistībā ar mediatora varu uzspiest strīdā iesaistītajām pusēm konkrētu risinājumu. Viens no risinājumiem ir Mediācijas likuma 3. panta grozī̌sana, kurā ietverts brīvprātības principa regulējums, papildinot to ar pušu tiesībām brīvi lemt par mediācijas procesā panāktas vienošanās saturu bez mediatora vai trešo personu iejaukšanās.

2. Latvijā izveidotā strīdu risināšanas sistēma un mediācijas kā viena no strīdu risināšanas veidiem institucionālā sistēma pašlaik nav atbilstoša Konvencijā noteiktajām prasībām dalībvalstīm un būtu pilnveidojama.

3. Lemjot par Latvijas pievienošanos Konvencijai individuāli vai kā Eiropas Savienības dalībvalstij, būtiski vērtēt mediācijas vienošanās izpildes iespējamību un efektivitāti, kā arī izvērtēt jau Latvijā darbojošos dokumentu atzīšanas un piespiedu izpildes mehānismu piemērotību Konvencijai atbilstošas mediācijas vienošanās atzīšanas un izpildes funkcijas istenošanai.

4. Virzot priekšlikumu par mediatora parakstìtu mediācijas vienošanos, tiesību aktos būtu nepārprotami jānosaka pušu un mediatora atbildības robeža saistībā ar mediācijas vienošanās saturu, likumā precīzi norādot, ka mediatora paraksts uz dokumenta ir apliecinājums mediācijas procesa norisei, izslēdzot iespēju tiesību aktu vai to piemērošanas prakses neatbilstošai interpretācijai strīda starp mediatoru un mediācijas dalībniekiem risināšanas gadỉjumā.

5. Tā kā Konvencijas piemērošana nav saistīta ar mediatora valstspiederību, sertificēšanas vai pakalpojuma sniegšanas vietu, Konvencijai stājoties spēkā, ètikas neievērošana jebkura mediatora darbā, tajā skaistā Latvijā sertificèta mediatora, var ietekmēt mediācijas vienošanās atzišanu un izpildi

${ }^{39}$ Konvencijas 5. panta pirmās daḷas (e) apakšpunkts.

${ }^{40}$ Konvencijas 5. panta pirmās daḷas (f) apakšpunkts. 
Konvencijas dalībvalstīs, ja attiecīgais mediators ir vadījis mediāciju, kuras rezultātā ir noslēgta vienošanās un attiecīgā vienošanās ir izpildāma kādā no tām.

6. Latvijā īpaša vērība pievēršama mediatoru darba kvalitātes uzraudzības sistēmas izveidei vai sertificētu mediatoru gadỉjumā - pilnveidei, tādējādi izvairoties no negatīva valsts tēla veidošanas strīdu risināšanas jomā, kas ir būtiski investoru piesaistē un valsts attīstîbai kopumā. Kvalitatīva mediatoru darba uzraudzības sistēma veicinātu strīdu risināšanas kultūras attīstību, tostarp nodrošinot pieeju tiesiskumam sabiedrības grupām ar atškirīgām vajadzībām. 